\title{
Molecular detection of Anaplasma bovis, Ehrlichia canis and Hepatozoon felis in cats from Luanda, Angola
}

Ana Cristina Oliveira', Maria Francisca Luz', Sara Granada ${ }^{1}$, Hugo Vilhena ${ }^{2,3,4}$, Yaarit Nachum-Biala ${ }^{5}$, Ana Patrícia Lopes ${ }^{4,6}$, Luís Cardoso ${ }^{4,6}$ and Gad Baneth ${ }^{5^{*}}$ (I)

\begin{abstract}
Background: Molecular identification of tick-borne pathogen infection in cats from Africa is scarce. The presence of bacterial (Anaplasma and Ehrlichia) and protozoal (Babesia and Hepatozoon) agents was investigated in blood samples from 102 domestic cats from Luanda, Angola, by polymerase chain reaction and DNA sequencing.

Results: Three cats (2.9\%) were found infected with Ehrlichia canis, three (2.9\%) with Hepatozoon felis and one (1.0\%) with Anaplasma bovis. The prevalence of infections with one single agent was $4.9 \%$, and that of infection with two agents (i.e. E. canis and H. felis) was 1.0\%. In total, six cats (5.9\%) were found infected with at least one of the detected tick-borne agents.

Conclusions: This is the first report of A. bovis, E. canis and H. felis in cats from Angola. To the best of our knowledge, A. bovis is also being reported for the first time in domestic cats outside of Japan. Cats are at a low to moderate risk of being infected with tick-borne agents in Luanda.
\end{abstract}

Keywords: DNA sequencing, Feline vector-borne diseases, Polymerase chain reaction, Tick-borne pathogens

\section{Background}

Bacteria and protozoa transmitted by various arthropods including ixodid ticks cause several diseases in cats $[1,2]$. Some of those vector-borne agents have a zoonotic character, i.e. they may be transmitted from animals and infect humans [3]. From a clinical point of view, vector-borne infections pose a diagnostic challenge because of their nonspecific manifestations and often subclinical nature [4]. Molecular methods, namely the polymerase chain reaction (PCR) and DNA sequence analysis, are useful for the diagnosis of individual clinical cases as well as for epidemiological studies on tick- and other vector-borne agents $[5,6]$.

Infection with several species of tick-borne bacteria and protozoa has been described in felids from Africa [7-9], but no molecular data are available on tick-borne pathogens in cats from Luanda, Angola. In this study,

\footnotetext{
* Correspondence: gad.baneth@mail.huji.ac.il

${ }^{5}$ Koret School of Veterinary Medicine, The Hebrew University of Jerusalem,

Rehovot, Israel

Full list of author information is available at the end of the article
}

agents of the genera Anaplasma, Babesia, Ehrlichia and Hepatozoon were surveyed in blood samples from 102 domestic cats from Luanda, Angola, by PCR and DNA sequencing.

\section{Methods}

\section{Cats and samples}

Domestic cats $(n=102)$ were sampled at "Casa dos Animais" veterinary clinic in Luanda, Angola, from May 2014 to February 2016. Available data are displayed by independent variables and their categories in Table 1. The age of cats ranged from 2.5 to 143 months (median: 12 months; interquartile range: 7.5-24).

Blood was collected in EDTA tubes and centrifuged, with two thirds of the plasma volume separated from cells and the remaining plasma frozen together with cells at $-20{ }^{\circ} \mathrm{C}$. DNA was extracted from the concentrated blood samples using a commercial kit (E.Z.N.A. Blood DNA Mini Kit, Omega Bio-Tek, Norcross, GA, USA), according to the manufacturer's instructions. 
Table 1 Prevalence of tick-borne pathogens in 102 cats from Luanda, Angola, as determined by PCR and DNA sequencing

\begin{tabular}{|c|c|c|c|}
\hline Variable/Category & $\begin{array}{l}\text { No. of cats } \\
\text { tested (\%) }\end{array}$ & $\begin{array}{l}\text { Percentage }(n) \\
\text { of infected cats }\end{array}$ & $95 \% \mathrm{Cl}(\%)$ \\
\hline Gender & 101 & & \\
\hline Female & $56(55.4)$ & $5.4(3)$ & $1.1-14.9$ \\
\hline Male & $45(44.6)$ & $6.7(3)$ & $1.4-18.3$ \\
\hline Breed & 96 & & \\
\hline Mixed & $92(95.8)$ & $6.5(6)$ & $2.4-13.7$ \\
\hline Defined $^{a}$ & $4(4.2)$ & $0.0(0)$ & $0.0-60.2$ \\
\hline Age group & 100 & & \\
\hline Juvenile ${ }^{b}$ & $50(50.0)$ & $6.0(3)$ & $1.3-16.5$ \\
\hline Adult ${ }^{c}$ & $50(50.0)$ & $6.0(3)$ & $1.3-16.5$ \\
\hline Hair length & 102 & & \\
\hline Short & $85(83.3)$ & $7.1(6)$ & $2.6-14.7$ \\
\hline Medium or long & $17(16.7)$ & $0.0(0)$ & $0.0-19.5$ \\
\hline Housing & 102 & & \\
\hline Indoors & $37(36.3)$ & $0.0(0)$ & $0.0-9.5$ \\
\hline Outdoors or mixed & $65(63.7)$ & $9.2(6)$ & $3.5-19.0$ \\
\hline Contact with other animals & 97 & & \\
\hline No & $20(20.6)$ & $0.0(0)$ & $0.0-16.8$ \\
\hline Yes $^{d}$ & $77(79.4)$ & $7.8(6)$ & $2.9-16.2$ \\
\hline Travel $^{\mathrm{e}}$ & 102 & & \\
\hline No & $60(58.8)$ & $3.3(2)$ & $0.4-11.5$ \\
\hline Yes & $42(41.2)$ & $9.5(4)$ & $2.7-22.6$ \\
\hline Ectoparasiticides & 91 & & \\
\hline No & $84(92.3)$ & $6.0(5)$ & $2.0-13.3$ \\
\hline Yes $^{f}$ & $7(7.7)$ & $14.3(1)$ & $0.4-57.9$ \\
\hline Fleas & 102 & & \\
\hline No & 89 (87.3) & $5.6(5)$ & $1.9-12.6$ \\
\hline Yes $^{9}$ & $13(12.7)$ & $7.7(1)$ & $0.2-36.0$ \\
\hline Clinical status & 102 & & \\
\hline Apparently healthy & 89 (87.3) & $6.7(6)$ & $2.5-14.1$ \\
\hline Sick ${ }^{h}$ & $13(12.7)$ & $0.0(0)$ & $0.0-24.7$ \\
\hline Total & $102(100)$ & $5.9(6)^{\mathrm{i}}$ & $2.2-12.4$ \\
\hline
\end{tabular}

Abbreviations: 95\% Cl 95\% confidence interval

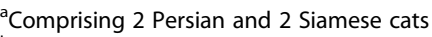

${ }^{\mathrm{b}} 2.5-11.5$ months

c $12-143$ months

IIncluding cats, dogs, rodents and/or birds

eOutside the province of Luanda

${ }^{f}$ Fipronil

${ }^{9}$ Not identified

${ }^{h}$ Clinical manifestations and laboratory abnormalities: anemia, anorexia/

hyporexia, cough, cutaneous lesions, diarrhea, fever, leukocytosis, leukopenia, neurological disorders, ocular signs, thrombocytopenia, weight loss, vomiting

'Anaplasma bovis $(n=1)$, Ehrlichia canis $(n=3)$ and Hepatozoon canis $(n=3)$,

including 1 cat co-infected with both $E$. canis and $H$. felis

\section{DNA amplification and sequencing}

All DNA samples were screened for the presence of Anaplasma and Ehrlichia spp. in duplicates by a real time PCR assay targeting a $123 \mathrm{bp}$ fragment of the $16 \mathrm{~S}$ ribosomal RNA (rRNA) gene using the primers E.c 16Sfwd (5'-TCG CTA TTA GAT GAG CCT ACG T-3') and E.c 16S-rev (5'-GAG TCT GGA CCG TAT CTC AG-3'), as previously described [10]. PCR amplification was performed using the StepOnePlus real-time PCR thermal cycler (Applied Biosystems, Foster City, CA, USA) in a total volume of $20 \mu \mathrm{l}$ containing $4 \mu \mathrm{l}$ DNA, $400 \mathrm{nM}$ of each primer, $10 \mu \mathrm{l}$ Maxima Hot Start PCR Master Mix $(2 \times)$ (Thermo Scientific, Epsom, Surrey, UK), $50 \mu \mathrm{M}$ of SYTO9 solution (Invitrogen, Carlsbad, CA, USA) and sterile DNase/RNase-free water (Sigma, St. Louis, MO, USA). Initial denaturation for $5 \mathrm{~min}$ at $95{ }^{\circ} \mathrm{C}$ was followed by 40 cycles of denaturation at $95{ }^{\circ} \mathrm{C}$ for $5 \mathrm{~s}$, annealing at $59{ }^{\circ} \mathrm{C}$ for $30 \mathrm{~s}$, and a final extension at $72{ }^{\circ} \mathrm{C}$ for $20 \mathrm{~s}$. Amplicons were subsequently subjected to a melt step with the temperature raised to $95{ }^{\circ} \mathrm{C}$ for $10 \mathrm{~s}$ and then lowered to $60{ }^{\circ} \mathrm{C}$ for $1 \mathrm{~min}$. The temperature was then raised to $95{ }^{\circ} \mathrm{C}$ at a rate of $0.3{ }^{\circ} \mathrm{C}$ per second. Amplification and melt profiles were analyzed using the StepOnePlus software v.2.2.2 (Applied Biosystems). Positive samples were further analyzed by a conventional PCR using the primers EHR16SD (5'-GGT ACC YAC AGA AGA AGT CC-3') and EHR16SR (5'-TAG CAC TCA TCG TTT ACA GC-3') [11] targeting a 345 bp fragment of the $16 S$ rRNA gene. PCR was performed using a programmable conventional thermocycler (Biometra, Göttingen, Germany). The reaction was done using PCRready High Specificity mix (Syntezza Bioscience, Jerusalem, Israel) in a total volume of $25 \mu \mathrm{l}$ including $500 \mathrm{nM}$ of each primer and sterile DNase/RNase-free water (Sigma). Amplification was performed with an initial denaturation at $95{ }^{\circ} \mathrm{C}$ for $5 \mathrm{~min}$, followed by 35 cycles of denaturation at $95{ }^{\circ} \mathrm{C}$ for $30 \mathrm{~s}$, annealing at $57{ }^{\circ} \mathrm{C}$ for $30 \mathrm{~s}$, and a final extension at $72{ }^{\circ} \mathrm{C}$ for $30 \mathrm{~s}$. After the last cycle, the extension step was continued for a further $5 \mathrm{~min}$. PCR products were electrophoresed on $1.5 \%$ agarose gels stained with ethidium bromide and evaluated under UV light for the size of amplified fragments by comparison to a 100 bp DNA molecular weight marker. DNA extracted from an Ehrlichia canis cell culture and from the blood of a dog infected with Anaplasma platys confirmed by PCR and sequencing were used as positive controls in all reactions.

Testing for the presence of Babesia and Hepatozoon spp. was performed by screening all DNA samples by a conventional PCR using the primers Piroplasmid-F (5'-ATA CAT GAG CAA AAT CTC AAC-3') and Piroplasmid-R (5'-CTT TCG CAG TAG TTY GTC TTT AAC AAA TCT-3'), which amplify a 350-400 bp fragment of the $18 S$ rRNA gene of Hepatozoon spp. and Babesia spp. [12]. The reaction was done as above except for the annealing temperature, which was $64{ }^{\circ} \mathrm{C}$. DNA samples extracted from a dog infected with Hepatozoon canis and from another dog infected with Babesia vogeli confirmed by PCR and sequencing were used as positive controls. 
DNA from the blood of a laboratory-bred pathogen free dog was used as a negative control. Non-template control reactions were done using the same procedures and reagents described above, but without DNA added to the PCR to rule out contamination and non-specific reactions. Negative uninfected dog DNA, and non-template DNA controls were used in each run for all pathogens.

All positive PCR products were sequenced at Hy Laboratories Ltd. (Rehovot, Israel) using the BigDye terminator v.1.1 Cycle Sequencing Kit (Applied Biosystems) on the ABI PRISM 3730xl DNA Analyzer. Raw data was analyzed using DNA Sequencing Analysis Software v.5.4. DNA sequences were evaluated with the ChromasPro software version 2.1.1 (Technelysium Pty Ltd., South Brisbane, QLD, Australia) and compared for similarity with sequences available in GenBank, using the BLAST program (http://www. ncbi.nlm.nih.gov/BLAST/). Species identity was determined as the closest BLAST match of at least $97-100 \%$ identity to an existing GenBank accession [13-15].

\section{Data analysis}

The Chi-square test (CST) and Fisher's exact test (FET) was used to compare proportions of positivity, considering a probability $(P)$ value $<0.05$ as statistically significant. Exact binomial 95\% confidence intervals (CI) were established for proportions. Analyses were done using the WinEpi, IBM SPSS Statistics 20 and StatLib softwares. Assuming a default expected prevalence of $50 \%$ and a confidence level of 95\%, a sample size of 102 units involves an absolute error of $9.7 \%$ [16].

\section{Results}

Three cats (2.9\%; 95\% CI: $0.6-8.3 \%)$ were found infected with E. canis, three (2.9\%; 95\% CI: 0.6-8.3\%) with Hepatozoon felis and one (1.0\%; 95\% CI: 0.0-5.3\%) with Anaplasma bovis. The prevalence of infection with one single agent was 4.9\% (95\% CI: $1.6-11.1 \%$ ), and that of coinfection with two agents (i.e. E. canis and $H$. felis) was $1.0 \%$ (95\% CI: $0.0-5.3 \%$ ) (FET: $P=0.097$ ). In total, six cats (5.9\%; 95\% CI: 2.2-12.4\%) were found infected with at least one of the detected tick-borne agents (Table 1). No statistically significant differences were found between positivity to any one of the three detected agents, either in single or coinfection, between the categories of gender, breed, age group, hair length, housing, contact with other animals, travel, ectoparasiticides, fleas and clinical status (Table 1). The identification of feline tick-borne agents according to the similarity of their amplified sequences with those available in the GenBank database is displayed in Table 2 (see also Additional file 1: Table S1).

All of the molecularly detected agents were found in apparently healthy cats. The cat found infected with $A$. bovis and one of the three other cats infected with $H$. felis had never travelled outside the province of Luanda.
The three cats found infected with $E$. canis, including one cat coinfected with $H$. felis, had travelled out of Luanda.

\section{Discussion}

This is the first description of A. bovis, E. canis and $H$. felis in cats from both Luanda and Angola. Furthermore, and to the best of our knowledge, A. bovis is also being reported for the first time in domestic cats outside of Japan [17]. Results of the present study suggest that domestic cats in Luanda are at a low to moderate risk of being infected with one or more of these three tickborne agents.

Although several vector-borne agents cause morbidity and mortality in domestic feline populations, the importance of some of them as a cause of disease has not yet been clearly determined [18]. All of the molecularly detected agents were found in apparently healthy animals, a situation which is in agreement with the generally subclinical nature of these infections [2]. Nevertheless, further studies are necessary to determine the real impact of these agents in cats.

Anaplasma bovis infection has been reported from several countries and in a few vertebrate species [17], mainly affecting cattle, with fever, anemia, weight loss, lymphadenopathy, abortion and death. However, subclinical infections have also been documented [19]. The first detection of $A$. bovis in domestic felines was reported in two cats from the Ehime Prefecture in western Japan [17]. The two cats had stomatitis and coinfection with the feline immunodeficiency virus (FIV); and one of the cats also had anorexia, diarrhea and fever, and co-infection with the feline leukemia virus. Although both those cats had stomatitis, the association between $A$. bovis infection and clinical illness could not be established, because stomatitis is a common finding in cats with FIV infection [17]. Anaplasma bovis was additionally detected in blood from Tsushima leopard cats (Prionailurus bengalensis euptilurus) from Japan [20], in the same leopard cat subspecies from Korea [21] and in one Haemaphysalis longicornis nymph obtained from an Iriomote (leopard) cat $(P$. bengalensis iriomotensis) from Japan. Curiously, this last nymph was also found positive to $H$. felis [22].

Ehrlichia canis is the etiological agent of canine monocytic ehrlichiosis and its confirmed vectors are Rhipicephalus sanguineus (sensu lato) ticks [23]. Dogs infected with E. canis can present a wide spectrum of clinical conditions, from subclinical infection to fatal illness [24]. Ehrlichia canis can also infect cats $[25,26]$, and human infections of a specific $E$. canis strain have been reported from Venezuela [27]. Most clinical manifestations attributed to canine ehrlichiosis have also been described in infected cats $[23,26]$.

In general, feline Hepatozoon infections are mostly caused by $H$. felis, which has tropism to the myocardial 
Table 2 Tick-borne pathogens from the six positive cats and their similarity with sequences deposited in the GenBank database

\begin{tabular}{|c|c|c|c|c|c|}
\hline Primer & Closest GenBank accession & $\begin{array}{l}\text { Percent identity } \\
\text { (no. of cats) }^{\mathrm{a}}\end{array}$ & Agent & Sample ID & $\begin{array}{l}\text { New GenBank } \\
\text { accessions }\end{array}$ \\
\hline \multirow[t]{3}{*}{ E.c 16S-fwd/E.c 16S-rev } & KX987326 & $100(1)$ & Ehrlichia canis & 017 & na \\
\hline & KX987326 & $100(1)$ & Ehrlichia canis & 053 & na \\
\hline & KX987326 & $99\left(1^{b}\right)$ & Ehrlichia canis & 002 & na \\
\hline E.c 16S-fwd/E.c 16S-rev + EHR16SD/EHR16SR & KY425447 & $99(1)$ & Anaplasma bovis & 026 & MG431981 \\
\hline \multirow[t]{3}{*}{ Piroplasmid-F/Piroplasmid-R } & KY649442 & $100(1)$ & Hepatozoon felis & 063 & MG386484 \\
\hline & KY649443 & $100(1)$ & Hepatozoon felis & 056 & MG386483 \\
\hline & KY649443 & $99\left(1^{b}\right)$ & Hepatozoon felis & 002 & MG386482 \\
\hline
\end{tabular}

Abbreviations: na not available, as sequences < 200 bp cannot be deposited in GenBank (see also Additional file 1: Table S1)

anly sequence identity $\geq 97 \%$ was considered as positive

${ }^{\text {bSame animal }}$

and skeletal muscle tissues of cats, and seems to cause mostly subclinical infection [15]. Nevertheless, non-healthy cats from Cyprus were described as three times more likely to be infected with Hepatozoon spp. compared with healthy ones [3]. Among wild felids, $H$. felis was detected at a frequency of around 10\% in captive African lions (Panthera leo) from Zimbabwe [8]. In southern Italy, apart from $H$. felis, domestic cats have also been found singly infected with $H$. canis and Hepatozoon silvestris [28]. The vectors and routes of transmission of $\mathrm{H}$. felis are currently not known.

Even though it was not found in the present investigation, Babesia felis is an agent of clinical babesiosis among domestic cats in South Africa [7]. Based on reverse line blot (RLB) hybridization, Babesia leo, which was originally reported from African lions, was also detected in coinfection with $B$. felis in one domestic cat from this same country [29]. In addition, Babesia lengau, first described in cheetahs (Acinonyx jubatus), was incriminated as the etiological agent in two severe clinical cases in domestic cats also from South Africa [30].

Another recent molecular study of tick-borne pathogens in dogs $(n=103)$ from Luanda revealed that $20.4 \%$ of the dogs were infected with A. platys, $17.5 \%$ with $H$. canis, $5.8 \%$ with $E$. canis, $5.8 \%$ with $B$. vogeli, $1.0 \%$ with Babesia gibsoni and $1.0 \%$ with an unnamed Babesia sp. [31]. Almost $45 \%$ of the dogs were positive to at least one pathogen, which represents a statistically significant difference (CST: $\chi^{2}=6.38, d f=1, P<0.0001$ ) to the $5.9 \%$ found positive to at least one agent in cats in the present report. The percent levels of canine single (37.9\%) and co-infections $(6.8 \%)$ also represent significant differences (CST: $\chi^{2}=5.75, d f=1 ; P<0.0001$; and FET: $P=0.032$ ) to their corresponding feline values (i.e. 4.9 and $1.0 \%$, respectively). On the other hand, the difference between the molecular prevalence of canine $(5.8 \%)$ and feline $(2.9 \%) E$. canis infections was not statistically significant (FET: $P=$ $0.314)$. Lastly, in the present report, $H$. felis was detected at a $2.9 \%$ molecular prevalence, which significantly differs
(FET: $P=0.0006$ ) from the $17.5 \%$ of $H$. canis previously found in the domestic dogs from Luanda [31].

The significantly (CST: $\chi^{2}=6.38, d f=1, P<0.0001$ ) higher prevalence of tick-borne pathogens among dogs (44.7\%) from Luanda compared with cats $(5.9 \%)$ may be due to a more frequent exposure of the canine hosts to ticks. In fact, tick infestation in the study in dogs was $60.2 \%$, which is also significantly different (FET: $P<$ 0.0001) from the absence of ticks detected on cats (data not shown). Prevention of tick-borne infections in cats largely relies on the regular and long-lasting application of effective acaricide products on individual animals for vector control. Fipronil, macrocyclic lactones, flumethrin and isoxazolines, administered individually or in combination, are among the active ingredients available on the global market for the control of tick infestations in cats [32-34].

The sampled domestic cats might not accurately represent the overall feline population of both Luanda and Angola, and additional studies also including potential vector ticks are needed for a more comprehensive clinical and epidemiological assessment. Under this circumstance, the present preliminary and geographically localized study may have limited the detection of a higher prevalence and even a wider variety of tick-borne agents [35]. Concerning other vector-borne pathogens, all the cats assessed in the present study were found negative for immunoglobulin G antibodies to Leishmania spp. by the DAT (direct agglutination test) [36].

\section{Conclusions}

In conclusion, this is the first report of A. bovis, E. canis and $H$. felis in felids from Luanda in Angola, where domestic cats are exposed to a low to moderate risk of becoming infected with tick-borne pathogens. Additional research is necessary, including a larger number of animals and feline populations from other cities and provinces, aiming at better characterizing and controlling feline vector-borne pathogens and their arthropod vectors in Angola. 


\section{Additional file}

Additional file 1: Table S1. DNA sequences of the $16 \mathrm{~S}$ rRNA gene from Ehrlichia spp. and Anaplasma spp. and 185 rRNA gene of Hepatozoon spp. amplified from cats positive to tick-borne pathogens. (DOCX $81 \mathrm{~kb}$ )

\section{Abbreviations}

95\% Cl: 95\% confidence interval; CST: Chi-square test; FET: Fisher's exact test; FIV: Feline immunodeficiency virus; PCR: Polymerase chain reaction: rRNA: Ribosomal RNA

\section{Acknowledgements}

Publication of this paper has been sponsored by Bayer Animal Health in the framework of the 13th CVBD World Forum Symposium.

\section{Funding}

Not applicable.

\section{Availability of data and materials}

All data generated or analyzed during this study are included in this published article.

\section{Authors' contributions}

ACO, MFL and SG performed clinical examination and collected samples. HV coordinated sample collection and participated in revising the manuscript. LC and APL extracted DNA. APL also revised the manuscript. YNB and GB performed PCR and sequencing. $L C, Y N B$ and $G B$ analyzed data and wrote the manuscript. All authors read and approved the final manuscript.

\section{Ethics approval and consent to participate}

This study was ethically approved by the scientific council of the Vasco da Gama University School as complying with the Portuguese legislation for the protection of animals (Law no. 92/1995 and Decree-Law no. 113/2013). Owners or legal holders provided their signed informed consent for inclusion of their animals in the study.

\section{Consent for publication}

Not applicable.

\section{Competing interests}

The authors declare that they have no competing interests.

\section{Author details}

${ }^{1}$ Clínica Casa dos Animais, Luanda, Angola. ${ }^{2}$ Center for Investigation Vasco da Gama (CIVG), Department of Veterinary Medicine, Vasco da Gama University School, Coimbra, Portugal. ${ }^{3}$ Baixo Vouga Veterinary Hospital, Águeda, Portugal. ${ }^{4}$ Animal and Veterinary Research Centre (CECAV), University of Trás-os-Montes e Alto Douro (UTAD), Vila Real, Portugal. ${ }^{5}$ Koret School of Veterinary Medicine, The Hebrew University of Jerusalem, Rehovot, Israel. ${ }^{6}$ Department of Veterinary Sciences, School of Agrarian and Veterinary Sciences (ECAV), UTAD, Vila Real, Portugal.

\section{Received: 22 February 2018 Accepted: 4 March 2018}

\section{Published online: 20 March 2018}

\section{References}

1. Alho AM, Lima C, Latrofa MS, Colella V, Ravagnan S, Capelli G, et al. Molecular detection of vector-borne pathogens in dogs and cats from Qatar. Parasit Vectors. 2017:10:298.

2. Díaz-Regañón D, Villaescusa A, Ayllón T, Rodríguez-Franco F, Baneth G, Calleja-Bueno L, et al. Molecular detection of Hepatozoon spp. and Cytauxzoon sp. in domestic and stray cats from Madrid, Spain. Parasit Vectors. 2017;10:112

3. Attipa C, Papasouliotis K, Solano-Gallego L, Baneth G, Nachum-Biala Y,

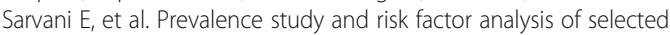
bacterial, protozoal and viral, including vector-borne, pathogens in cats from Cyprus. Parasit Vectors. 2017;10:130.

4. Otranto D, Dantas-Torres F, Breitschwerdt EB. Managing canine vector-borne diseases of zoonotic concern: part one. Trends Parasitol. 2009;25:157-63.
5. Otranto D, Dantas-Torres F, Breitschwerdt EB. Managing canine vector-borne diseases of zoonotic concern: part two. Trends Parasitol. 2009;25:228-35.

6. Baneth G. Tick-borne infections of animals and humans: a common ground. Int J Parasitol. 2014:44:591-6.

7. Penzhorn BL, Schoeman T, Jacobson LS. Feline babesiosis in South Africa: a review. Ann N Y Acad Sci. 2004;1026:183-6.

8. Kelly P, Marabini L, Dutlow K, Zhang J, Loftis A, Wang C. Molecular detection of tick-borne pathogens in captive wild felids, Zimbabwe. Parasit Vectors. 2014;7:514.

9. Alvarado-Rybak M, Solano-Gallego L, Millán J. A review of piroplasmid infections in wild carnivores worldwide: importance for domestic animal health and wildlife conservation. Parasit Vectors. 2016;9:538.

10. Peleg O, Baneth G, Eyal O, Inbar J, Harrus S. Multiplex real-time gPCR for the detection of Ehrlichia canis and Babesia canis vogeli. Vet Parasitol. 2010;173:292-9.

11. Parola P, Roux V, Camicas JL, Baradji I, Brouqui P, Raoult D. Detection of ehrlichiae in African ticks by polymerase chain reaction. Trans $\mathrm{R}$ Soc Trop Med Hyg. 2000;94:707-8

12. Tabar MD, Altet L, Francino O, Sánchez A, Ferrer L, Roura X Vector-borne infections in cats: molecular study in Barcelona area (Spain). Vet Parasitol. 2008;151:332-6.

13. Karagenc Tl, Pasa S, Kirli G, Hosgor M, Bilgic HB, Ozon YH, et al. A parasitological molecular and serological survey of Hepatozoon canis infection in dogs around the Aegean coast of Turkey. Vet Parasitol. 2006;135:113-9.

14. Allen KE, Li Y, Kaltenboeck B, Johnson EM, Reichard MV, Panciera RJ, et al. Diversity of Hepatozoon species in naturally infected dogs in the southern United States. Vet Parasitol. 2008;154:220-5.

15. Baneth G, Sheiner A, Eyal O, Hahn S, Beaufils JP, Anug Y, et al. Redescription of Hepatozoon felis (Apicomplexa: Hepatozoidae) based on phylogenetic analysis, tissue and blood form morphology, and possible transplacental transmission. Parasit Vectors. 2013;6:102

16. Thrusfield M. Veterinary Epidemiology. 3rd ed. Oxford: Blackwell Science; 2007.

17. Sasaki H, Ichikawa Y, Sakata Y, Endo Y, Nishigaki K, Matsumoto K, et al. Molecular survey of Rickettsia, Ehrlichia, and Anaplasma infection of domestic cats in Japan. Ticks Tick Borne Dis. 2012;3:308-11.

18. Ayllón T, Diniz PP, Breitschwerdt EB, Villaescusa A, Rodríguez-Franco F, Sainz A. Vector-borne diseases in client-owned and stray cats from Madrid, Spain. Vector Borne Zoonotic Dis. 2012;12:143-50.

19. Belkahia H, Ben Said M, Alberti A, Abdi K, Issaoui Z, Hattab D, et al. First molecular survey and novel genetic variants' identification of Anaplasma marginale, A. centrale and A. bovis in cattle from Tunisia. Infect Genet Evol. 2015;34:361-71

20. Tateno M, Nishio T, Sakuma M, Nakanishi N, Izawa M, Asari $Y$, et al. Molecular epidemiologic survey of Bartonella, Ehrlichia, and Anaplasma infections in Japanese Iriomote and Tsushima leopard cats. J Wildl Dis. 2013;49(3):646-52.

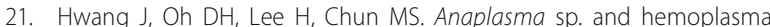
infection in leopard cats (Prionailurus bengalensis euptilurus) from Korea. Jet Sci. 2015:16:385-8.

22. Tateno M, Sunahara A, Nakanishi N, Izawa M, Matsuo T, Setoguchi A, et al. Molecular survey of arthropod-borne pathogens in ticks obtained from Japanese wildcats. Ticks Tick Borne Dis. 2015;6:281-9.

23. Neer TM, Breitschwerdt EB, Greene RT, Lappin MR. Consensus statement on ehrlichial disease of small animals from the infectious disease study group of the ACVIM. J Vet Intern Med. 2002;16:309-15.

24. Shaw SE, Day MJ, Birtles RJ, Breitschwerdt EB. Tick-borne infectious diseases of dogs. Trends Parasitol. 2001;17:74-80.

25. Breitschwerdt EB, Abrams-Ogg AC, Lappin MR, Bienzle D, Hancock SI, Cowan SM, et al. Molecular evidence supporting Ehrlichia canis-like infection in cats. J Vet Intern Med. 2002;16:642-9.

26. Little SE. Ehrlichiosis and anaplasmosis in dogs and cats. Vet Clin North Am Small Anim Pract. 2010:40:1121-40.

27. Perez M, Bodor M, Zhang C, Xiong Q, Rikihisa Y. Human infection with Ehrlichia canis accompanied by clinical signs in Venezuela. Ann N Y Acad Sci. 2006;1078:110-7. [erratum in: Ann N Y Acad Sci. 2010;1212:130]

28. Giannelli A, Latrofa MS, Nachum-Biala Y, Hodžić A, Greco G, Attanasi A, et al. Three different Hepatozoon species in domestic cats from southern Italy. Ticks Tick Borne Dis. 2017:8:721-4.

29. Bosman AM, Venter EH, Penzhorn BL. Occurrence of Babesia felis and Babesia leo in various wild felid species and domestic cats in southern Africa, based on reverse line blot analysis. Vet Parasitol. 2007;144:33-8. 
30. Bosman AM, Oosthuizen MC, Venter EH, Steyl JC, Gous TA, Penzhorn BL. Babesia lengau associated with cerebral and haemolytic babesiosis in two domestic cats. Parasit Vectors. 2013;6:128.

31. Cardoso L, Oliveira AC, Granada S, Nachum-Biala Y, Gilad M, Lopes AP, et al. Molecular investigation of tick-borne pathogens in dogs from Luanda, Angola. Parasit Vectors. 2016;9:252.

32. Stanneck D, Kruedewagen EM, Fourie JJ, Horak IG, Davis W, Krieger KJ. Efficacy of an imidacloprid/flumethrin collar against fleas and ticks on cats. Parasit Vectors. 2012;5:82

33. Tielemans E, Prullage J, Knaus M, Visser M, Manavella C, Chester ST, et al. Efficacy of a novel topical combination of fipronil, (S)-methoprene, eprinomectin, and praziquantel, against the ticks, Ixodes ricinus and Ixodes scapularis, on cats. Vet Parasitol. 2014;202:59-63.

34. Geurden T, Becskei C, Vatta AF, Slootmans N, von Reitzenstein M, King VL, et al. Efficacy of a new spot-on formulation of selamectin plus sarolaner against four common tick species infesting cats in Europe. Vet Parasitol. 2017;238(Suppl 1):S3-7.

35. Noden BH, Soni M. Vector-borne diseases of small companion animals in Namibia: Literature review, knowledge gaps and opportunity for a One Health approach. J S Afr Vet Assoc. 2015;86:E1-7.

36. Lopes AP, Oliveira AC, Granada S, Rodrigues FT, Papadopoulos E, Schallig H, et al. Antibodies to Toxoplasma gondii and Leishmania spp. in domestic cats from Luanda, Angola. Vet Parasitol. 2017;239:15-8.

\section{Submit your next manuscript to BioMed Central} and we will help you at every step:

- We accept pre-submission inquiries

- Our selector tool helps you to find the most relevant journal

- We provide round the clock customer support

- Convenient online submission

- Thorough peer review

- Inclusion in PubMed and all major indexing services

- Maximum visibility for your research

Submit your manuscript at www.biomedcentral.com/submit 